\title{
Abstracts of Papers Presented at the Annual Meeting
}

\author{
SESSION 1A: CORPORATIONS, ENTREPRENEURSHIP, AND REGULATION
}

\section{Corporate Entrepreneurship and Economic Growth in America, 1790-1860}

Before the U.S. Civil War, an estimated 200,000 entrepreneurs specially chartered over 20,000 start-up corporations in a wide variety of businesses from entertainment to financial services to manufacturing to transportation to utilities. The number and minimum authorized capital of those corporations, measured both as a flow and as a stock, may have Granger caused total U.S. nominal GDP. Corporations also probably caused economic growth in the traditional Greek sense of being one of the agents of economic development. They transformed the American economic landscape by supplying the economy with goods that could only have been created at higher cost by non-corporations. They simultaneously stimulated entrepreneurship by holding out the possibility of above normal returns. Some corporations created before the Civil War survive, in some form, to this day. Most, though, exited within a few decades. Their failures, however, were not net losses to the economy because they created valuable information and infrastructure before expiring and because their human, financial, and physical capital were put to new uses rather than destroyed.

ROBERT Wright, New York University

\section{Incorporating Industry: Nineteenth-Century General Incorporation Acts for Manufacturing Companies}

This paper analyzes the effects of general incorporation acts on the development of industrial corporations, using a newly collected data set of mid-nineteenth-century corporations from Massachusetts. Prior to such acts, an entrepreneur hoping to form a corporation had to petition a state legislature for a charter, a process that was often corrupted by bribes and influence peddling. General incorporation statutes made incorporation a simple matter of filing a certificate with the secretary of state. The paper presents a detailed analysis of the effect of Massachusetts's 1851 general incorporation act for manufacturing firms on the paid-in capital, rate of survival, diffusion of ownership, and sources of financing of the state's industrial corporations, using data obtained from the certificates of condition filed by all corporations in the state.

ERIC HILT, Wellesley College

\section{Controlling Capital, Creating Investors: State Public Service Commission Regulation} of Corporate Securities in Early-Twentieth-Century United States

This paper examines the policy proposals and regulatory activity aimed at controlling capital issues in the early twentieth century, with particular attention to state public service commission regulation of railroad and public utility securities. Economists and lawmakers targeted overcapitalization in electricity, gas, and street railway corporations, arguing that "watered stock" represented a mask for abnormal profits, an unwarranted tax on consumers, and a tool of stock speculation and market 
manipulation. Though securities markets were largely sophisticated enough to recognize water in traded securities, regulators aimed to shape the market for utility securities by transforming them from speculative vehicles into safe, low-risk investments for new middle-class investors. Politicians, regulators, and some financial leaders viewed this recasting of securities as a necessary step to fend off calls for government ownership, align the interests of utilities and communities, and fulfill growing capital needs of railroads and utilities in the 1910s and 1920s.

DANIEL HOLT, University of Virginia

\section{SESSION 1B: EDUCATION, INVESTMENT, AND INSTITUTIONS}

\section{Legal Institutions, Medieval Universities, and the Commercial Revolution}

Medieval Europe experienced a "commercial revolution," with urbanization and trade expanding, first in northern Italy, then across Europe. We argue that the development of a formal legal system throughout Europe played an important role in promoting the commercial revolution, and that the establishment of universities in Europe-which developed the legal system and trained the individuals who served it - was a fundamental institutional development that supported economic activity. We first present evidence of the commercial revolution, including data we compiled on markets and urbanization in Germany. Next, we show that university establishment and the training of individuals in the law were associated with the commercial revolution. To interpret this association causally, we exploit the creation of universities in Germany following the Papal Schism, and the subsequent development of legal institutions. Our results, based on grants of market rights, suggest that university establishment and legal development significantly increased economic activity.

NOAM Yuchtman, Harvard University, and DAVIDE CANTONI, Harvard University

Free Schools in America, 1850-1870: Who Voted for Them, Who Got Them, and Who Paid

American public schools, which have been mainly financed by local property taxes, were not entirely free until aids from states grew and local moneys were redistributed by states. This paper, concentrating on the period between 1850 and 1870 when common schools became free, investigates the long-existing intrastate inequality in public education with the following questions: How could the public school finance rules have changed, and what were the consequences? A political economy model, supported by statistical analyses, well explains historical events such as free school referenda in New York and Indiana. People favored less tax cost. Policies shifted toward redistribution over localities through imposing more tax burdens on the rich, who were minority in the referenda. Interstate analyses based on the decennial census data show that the centralization of school finance during the period increased the provision of public education and reduced intrastate inequality in public schooling across counties. 
A Hard Day's Night: Evening Schools and Child Labor in the United States, 18701910

Although scholars have made considerable progress in understanding the rise of public education and the impact of child labor and compulsory attendance legislation, the quantitative literature has neither documented nor analyzed an important feature of the educational movement-widespread efforts to enable children to combine work and schooling simultaneously. Evening schools, in particular, were common throughout the United States, and enrollment in these schools increased throughout the later part of the nineteenth century. This paper brings together information from a variety of sources to trace the history of the "public evening school movement" into the post-World War I period. The analysis examines diffusion patterns of evening schools and the impact these schools had on school attendance of working-class children. Findings suggest that the diffusion of evening schools comprised efforts to educate disadvantaged youths, assimilate immigrants, and alleviate overcrowding in schools. Evening schools helped youths fulfill compulsory schooling and work permit requirements.

LINDA CARTER, Vanderbilt University

SESSION 2A: RURAL ORGANIZATION AND INNOVATION

\section{Creative Destruction and Entrepreneurial Obstruction: Cuban Sugar, 1898-1939}

As Joseph Schumpeter developed his argument for "creative destruction," it was motivated, in part, as a warning against contemporary policies intended to obstruct it. The paper examines the role of creative destruction, entrepreneurial activity, and the role of institutions in two important episodes in the economic history of Cuba, from 1898 to 1929 and from 1929 to 1939 , through the examination of entry, survival, and exit patterns of sugar mills and firms. Direct examination of the data is accompanied by discrete survival analysis to test for differences in entry, survival, and exit patterns in the favorable institutional environment of the former period against the unfavorable institutional environment of the latter. Entry, survival, and exit patterns and production cost estimates give evidence of a thriving entrepreneurial environment that facilitated process innovation in the former period but obstruction of entrepreneurial activity in the latter with negative long-run consequences on costs and competitiveness.

Alan Dye, Barnard College

Agricultural Innovation, Environmental Destruction, and the Exploitation of Accumulated Human Capital: Chesapeake Planters, 1790-1820

At the turn of the nineteenth century, elite Chesapeake planters heeded the advice of agricultural reformers by de-emphasizing tobacco or eliminating it altogether in favor of grains, and by embarking on a course of improving agriculture. They succeeded in expanding improved acreage and outputs per worker, reaped record profits, and began investing in internal improvements and commercial ventures as well as in their plantations. Possession of enslaved workforces experienced in both traditional tobacco agriculture and high-style wheat farming enabled planters to take 
advantage of windfall wartime profits by quickly shifting their crop mix in response to changing markets. Agricultural innovations, however, failed to produce sustained growth, due in large measure to the unintended environmental destruction that accompanied the adoption of farming techniques inappropriate to the region's soils and topography, as well as to the deleterious effects of the panic of 1819.

LOREna Walsh, Colonial Williamsburg Foundation

\section{Democracy Under the Tsars? The Case of the Zemstvo}

The emancipation of the serfs is often viewed as watershed moment in nineteenthcentury Russian history. However, this reform was accompanied by numerous others measures aimed at modernizing the tsarist economy and society. Among these "great reforms" was the creation of a new institution of local government - the zemstvowhich has received comparatively little attention from economic historians. This quasi-democratic form of local government played a vital role in expanding the provision of public goods and services in the half century leading up to the Russian Revolution. In this two-part paper, I first outline the political and organizational structure of the zemstvo, outline the institution's various sources of revenue, and summarize its expenditures. In the second part of the paper, I draw on newly collected data from several years of spending and revenue decisions by district zemstva. These data are matched to information on local socioeconomic conditions to produce one of the first panel data sets with broad geographic coverage on any topic in Russian economic history. I use this data set to investigate how population characteristics, local economic conditions, and mandated peasant representation in the zemstva influenced funding decisions over public goods. Through their representation in this local political institution, were peasants able to voice their preferences over spending levels and funding for specific initiatives? I find evidence consistent with zemstvo responsiveness to local economic conditions and the demands of the peasant population. This study initiates a broader research agenda into the zemstvo's place in Russian economic history and contributes to the literature on the political economy of public good provision in developing societies.

SteVen NAFZIGER, Williams College

\section{SESSION 2B: INTELLECTUAL PROPERTY RIGHTS AND MARKETS}

\section{The Emergence of Rights-Based Multinationals: Sunk Costs, Intellectual Property Rights, and the Political Economy of Globalization, 1870-2000}

This paper argues that the legal and institutional evolution of intellectual property rights went hand in hand with a new form of organization for their "production" and distribution. The rights-based multinational is defined as an organization that focused on generating intellectual property rights and maximizing and capturing their rents. It linked an international federation of idiosyncratically dispersed R\&D units (each with a maximum scale and scope) to a global distribution system with subsidiaries in all major markets and a minimum scale and scope. The portfolio of rights generated enabled the diversification of risk. An essential feature was that sunk costs were extremely high, while marginal costs were infinitesimal. Combining economic history with transaction cost and institutional economics, this paper explores the political, economic, and social implications of "zero" marginal costs for the process of 
globalization and examines the development of rights-based multinationals in industries such as pharmaceuticals, software, and music.

GERBEN BAKKER, London School of Economics

The Market for Patents in Imperial Germany

In this paper, we investigate the evolution of the market for patents in the German Empire during the period 1877-1913. Our analysis based on a comprehensive data set of more than 20,000 transfers registered at the German patent office. In 1877 the first unified German patent law was enacted, creating transferable intellectual property rights. From the outset, about 2-3 percent of the valid patents were transferred annually. In particular, individual inventors transferred their patents to firms; new firms were established on the basis of patents. Moreover, patent lawyers acted as intermediaries on the market for patents. We investigate stylized facts of the market using regression techniques.

CARSTEN BURHOP, Max Planck Institute

The Democratization of Invention in the American South: Antebellum and Postbellum Technology Markets in the United States

Patenting expanded rapidly across the postbellum South as its transportation network filled in and city growth extended markets. This was consistent with Kenneth L. Sokoloff and B. Zorina Khan (1990), who demonstrated the elastic supply of patentable ideas in early America. Successful innovation required that inventors could or did sell their property rights through "assignment" to those who commercialized new technology. The assignment characteristics of 1912 southern patents were examined. Southern "border" state patents had a higher rate of marketable assignments than those issued to residents in the Deep South. Greater commercialization of patents in border state cities accounted for most of this difference.

WILLIAM PHILLIPS, Tulane University

\section{SESSION 2C: CHINESE ECONOMIC DEVELOPMENT}

\section{Economic Growth and the Medium-Long Cycles in Modern China}

What characterized the state of Chinese economic situation over the century between the Opium War in 1840 and the Communist takeover in 1949, growth, stagnation, or decline? Were there distinctive periods or cycles? In this paper, the author provides a preliminary statistical analysis of the period 1880-1936. This paper consists of three parts. The first part provides a statistical profile of economic growth and industry structural change. The second part discusses the medium and long cycles. The third part analyzes the general tendency and three periods of economic development in modern China. 
Changes in the Wuxi Rural Economy and the Possibility of Successful Transformation into a Modern Economy

The research assesses the moving trend of net income per capita in the rural economy of Wuxi by tracking changes in population, land, agricultural productivity, and peasant household economic structure from the 1840s to the 1940s. The research shows that Wuxi peasants enjoyed a higher standard of living from the 1870s to the 1920 s due to the rise of sericulture stimulated by international demand for Chinese raw silk and the reduction in population caused by the Taiping rebellion. In the 1930s1940 s the standard of living retreated back to the level of the $1840 \mathrm{~s}-1850 \mathrm{~s}$ as a result of the decline of sericulture, which was caused mainly by sharply decreasing international market demand for Chinese raw silk. The development of industry and urban economy alleviated the situation by absorbing rural laborers into the modern economic sectors, but was insufficient to offset the falling income in sericulture. Given the constraints of population, land, and productivity, and with the decline of sericulture and limited development of industry and the urban economy, it is unlikely that the Wuxi rural economy in the early twentieth century could have been transformed into a modern one.

ZHANG LI, Nankai University

\section{Incentives and Information: An Institutional Interpretation of Traditional Chinese State and Great Divergence}

This article delineates the political logic of Chinese empire in the framework of a principal-agent model with three major actors: the emperor, the bureaucracy, and the people. In the absence of government credible commitment in late Imperial China, the private information sets by the bureaucrat and the people, while tying the grabbing hands of an absolutist empire, simultaneously weakens the state's fiscal and legal capacity to clarify or support property rights and contract enforcement. Furthermore, the withholding of private information also inhibits the societal capacity to organize collective action and severely curtails possibilities for institutional change in favor of economic growth within the political regime. I emphasize that it is these internal political and institutional features-rather than resource or factor endowments as emphasized in recent revisionist scholarship-that explain better the economic divergence between China and Western Europe in the early modern period.

DEBIN MA, London School of Economics

\section{SESSION 3A: AFRICA AND COLONIZATION}

\section{The Transatlantic Slave Trade and the Evolution of Mistrust in Africa: An Empirical Investigation}

Trust is increasingly perceived as having a significant effect on trade, public goods provision, conflict resolution, and even democratic consolidation. In this paper, we investigate the historical determinants of trust within Africa, by testing for a long-term impact of the intensity of the slave trades on the level of interpersonal trust and trust in local institutions. We find that the number of slaves taken from an ethnic group between 1400 and 1900 is negatively correlated with how much individuals from that 
group trust others, especially those closest to the respondent, such as co-ethnics, relatives, and neighbors. A history of slaving is negatively correlated with trust of governments, and this effect is stronger for local governments than for national governments. This is true even controlling for individual's perception of government's performance. We confirm that the effect of slave exports on trust is causal by using the historic distance between the geographic location of ethnic groups and the coast as an instrument for the number of slaves taken from that group.

NATHAN NUNN, Harvard University, and LEONARD WANTCHEKON, New York University

\section{Guns for Slaves: The Eighteenth-Century British Slave Trade}

The transatlantic slave trade was a triangular trade that touched Europe, Africa, and the Americas. The elasticity of supply of enslaved Africans is at the center of our understanding of each of these episodes. It helps explain the structure and scale of early Atlantic trade; it is at the center of explanations of the transition from indenture servitude to slavery in the Americas; and it helps estimate the depth of the social upheaval in Africa. In this paper, I estimate the first enslaved African export supply functions. Data come from the eighteenth-century British triangular trade. Econometric specifications are informed by three conceptions of the supply process: indigenous warfare, economic incentives, and guns for slaves. Two-stage least squares and instrumental variables estimation produce strong support for the guns-for-slaves conception. Rather than being a stable price-elastic supply function, as assumed by scholars working on both sides of the Atlantic, guns and gunpowder shifted out the supply function in a systematic way, producing what appeared to American planters as an unlimited supply of African slaves, and what in Africa became underdevelopment.

WARREN WHATLEY, University of Michigan

\section{Heart of Darkness, 1919-1939: Did French Colonial Investment Pay?}

During the interwar period, the French colonial empire reached its apogee. How much market share did the colonial firms have in the Parisian stock market? What were the features of this set of investment opportunities available to French investors? Just before the start of decolonization process, we address the issue of financial performances of French colonial portfolios. Did the French investors benefit from geographic diversification allocating a significant fraction of their portfolio to colonial securities listed in the Paris Stock Exchange in an economic area supposed integrated? More precisely, our question is whether a country diversification including colonial firms yielded more efficient portfolios than an industry diversification based on metropolitan firms. 


\section{SESSION 3B: EVOLUTION OF HEALTH CARE PRACTICES AND INSTITUTIONS}

\section{Family Size and the Heights of Children in Britain, 1900-1940}

In this paper, we argue that the fertility decline that began around 1880 had substantial positive effects on the health of children, as the quality-quantity trade-off would suggest. We use microdata from a unique survey from 1930s Britain to analyze the relationship between the standardized heights of children and the number of children in the family. Our results suggest that heights are influenced positively by family income per capita and negatively by the number of children or the degree of crowding in the household. The evidence suggests that family size affected the health of children through its influence on both nutrition and disease. Applying our results to long-term trends, we find that rising household income and falling family size contributed significantly to improving child health between 1886 and 1938. Between 1906 and 1938 these variables account for half of the increase in heights, and much of this effect is due to falling family size. We conclude that the fertility decline is a neglected source of the rapid improvement in health in the first half of the twentieth century.

Timothy HatTon, Australian National University, and RICHARD MARTIN, University of Bristol

\section{Physician Supply Inequality in the United States During the Early Twentieth Century}

The United States experienced a disproportionate decrease in the number of physicians per capita in rural areas relative to urban areas during the early twentieth century. The existing literature has offered many potential explanations for the increased urbanization of physicians, but the hypotheses have not been rigorously tested with data on substantial numbers of physicians. This paper uses individual-level data on approximately 100,000 physicians to examine variation in physician supply across counties in the United States during this period. Regression results are consistent with assertions in the existing literature that physicians were drawn to areas offering better financial opportunities, greater access to medical facilities, and more opportunity for professional contact. More detailed analysis of physician migration indicates that recent medical school graduates were more apt to move from a rural to an urban area. The results also suggest a growing importance of females to a physician's practice.

JARET TREBER, Kenyon College, and Melissa Thomasson, Miami University

\section{Identifying, Separating, and Managing Asymmetric Information in Early-Twentieth- Century Health Insurance}

Contrary to theoretical and intuitive expectations, little empirical evidence of asymmetric information in insurance contracts has emerged. Further, the prospective difficulties of distinguishing between moral hazard and asymmetric information are considerable. This paper addresses these issues using historical data on master contracts for a large number of early group health policies. Contemporary publications indicated awareness of information problems and of their potential solutions. This 
paper provides evidence of each information problem, and then shows how sickness insurance funds managed them. Longer probationary periods before applicants became covered reduced adverse selection. Longer waiting periods before claimants could receive benefits reduced the moral hazard of paid sick leave. These findings support previous claims of the fundamental institutional soundness of early forms of health insurance.

JOHN MURRAY, University of Toledo

\section{SESSION 3C: HUMAN CAPITAL CREATION}

\section{The Practice of Apprenticeship in Early Modern England}

Apprenticeship was the central formal institution for transmitting skills in premodern Europe. Yet little is known about how apprenticeship functioned in practice. This paper analyzes the internal characteristics of apprentices' service in two of England's major centers of training, London and Bristol, in the 1690s and 1700s. By reconstructing masters' households over time using tax records, we observe apprentices' movements during their training, the stability and failure of contracted relationships, and the extent of involvement before and after the period of formal contracting. Our analysis confirms suspicions that large numbers of apprentices left their masters prematurely. We also find distinctive differences between patterns of apprenticeship in the two cities, and offer the first analysis of factors explaining different trajectories through apprenticeship. We conclude that the structures for acquiring human capital in premodern England were significantly more flexible and fluid than has traditionally been thought.

PATRICK WALLIS, London School of Economics

\section{The Engineer as a Catalyst of Innovation and Creative Destruction: Industry Case Studies from Twentieth-Century Britain}

Schumpeter's account of creative destruction assigns a prominent role to the entrepreneur. This paper considers whether engineers deserve to be given more prominence in understanding differences between the evolution of enterprises in the United States and Britain. It considers the rise of the engineering profession in the two countries and the ways in which engineers may have contributed to innovation, not only directly through research and development activities, but through more indirect administration, production, and other operational activities. The underutilization of the engineering profession has been cited as one of the factors in Britain's loss of technological leadership over the course of the twentieth century. This has sometimes been attributed to what has been labeled the "practical man syndrome." This study considers three key industries - automobiles, aircraft, and electronics. In each of these industries, at some point, Britain had a key technological advantage and by some accounts this advantage was lost due to failure to more fully incorporate engineers into enterprise operations. This was particularly the case for the automobile industry. The experience of the automobile industry suggests that the interaction between the individual innovator and the evolving organization of enterprise may have influenced the capacity of the enterprise to innovate through utilization of engineers.

DAVID MITCH, University of Maryland 


\section{From Farm to Factory to School}

This paper utilizes a broad range of new and old evidence to argue that continuing innovation in both farming and manufacturing, from 1730 to 1830 , raised productivity and the material standard of living in rural New England but rested on the bodies of the region's most vulnerable class of laborers. Although children provided the kickstart to the Industrial Revolution in New England, continuing technological change was phasing them out just as reformers were seeking to put them all in school.

GLORIA MAIN, University of Colorado

\section{SESSION 4A: DEMOGRAPHIC CHANGES}

\section{The May-December Relationship Since 1850: Age Homogamy in the United States}

The gap between the ages of husbands and wives in the United States fell in each decade from 1900 to 2000 . We explore whether this trend was present as well in the second half of the nineteenth century using data from the 1850-1880 IPUMS samples. We find that age homogamy (similarity in the ages of spouses), measured in a variety of ways, actually decreased after 1850 before beginning its twentieth-century increase. The post-1850 decrease in homogamy did not result from the loss of marriageage males in the Civil War or from the withdrawal of women from paid labor in industries that employed large numbers of women in early industrialization (e.g., textiles). Rather, the rising age gap resulted from the lack of same-age partners and the desire for younger, more physically vigorous wives in newly settled regions and high-mortality locations such as southern counties with large slave populations.

JOSEPH FERRIE, Northwestern University, and KAREN ROLF, University of Nebraska

\section{What Do Women Do: Is Fertility Decline Universal?}

In this paper, we want to test the positive role of women's education on economic growth. It is well known that in some of the Western societies the education of mothers had as an effect higher education for children and the diminution of fertility rates. In this paper, we want to go one step further and to examine if the model can apply to other societies, particularly poor countries of Africa, East and South Asia, and Latin America. We also want to speculate on the amount of growth world societies lose because of the low level of women's education.

\section{STANLEY ENGERMAN, University of Rochester, and} ENRIQUETA CAMPS, Universitat Pompeu Fabra

\section{Household Choice of Technique in the Fog of Uncertainty: Strategies of Fertility Control and Patterns of Choice During the German Fertility Transition, 1895-1915}

An extensive body of literature, mostly drawn from the Princeton project on the European fertility transition, is based on the critical assertion that fertility control during the transition was parity dependent. The indirect evidence for this proposition is flawed. Following up on an argument formulated by Gigi Santow (1995) and Paul 
A. David and Warren C. Sanderson (1986), this paper revisits the question of control during the transition by placing it within the framework of dynamic models of fertility under uncertainty. It examines the choice of technique and the strategy for family building during the period of the transition in Germany during the period 1885 to 1915. The paper shows that available technologies varied in efficiency, cost, and disutility, which posed significant trade-offs for couples. After establishing the relative efficiency of most of the technologies available to couples, the paper examines the decision to use birth control and the choice of birth control strategy. The econometric analysis uses a detailed survey of fertility outcomes, birth control practices, and social and economic information that includes most of the period of the transition. The results suggest that the logic of birth control technologies and desired family size created a bifurcated distribution of strategy choices.

JOHN BROWN, Clark University

SESSION 4B: URBAN TRANSFORMATIONS

\section{Urban Entrepreneurship in the Post-Civil Rights South}

Analyzes the impact of the 1960s Civil Rights revolution on economic development in metropolitan areas of the South, using Charlotte, Little Rock, and Birmingham, as illustrative case studies. Recent adverse assessments have overlooked or downplayed several noteworthy trends, such as the reversal of black regional migration flows since 1970; the rapid rise of southern black incomes; the growth of black-owned businesses and middle-class communities in southern cities; and the advent of active competition for black tourists, especially to historic Civil Rights sites in the South.

GAVIN WRIGHT, Stanford University

\section{The Decline of an Innovative Region: Cleveland in the Twentieth Century}

Cleveland provides a useful example of a center of innovation that ultimately lost its dynamism. Once a hotbed of startup enterprises in a remarkable number of important Second Industrial Revolution industries, including electric light and power, steel, petroleum, chemicals, and automobiles, Cleveland is now a poster child for deindustrialization and urban decay. In this paper, we study Cleveland to further our understanding of the life cycle of high-tech regions. We examine patent data, linked to occupational and demographic data on inventors and to credit and financial data on innovative firms, to explore trends in the productivity and organization of Cleveland's inventive community. We find evidence of changes in Cleveland's economy beginning in the 1920s. Although local inventors continued to spawn new enterprises, their contributions to the stock of patented technology were generally smaller than in previous decades, and the most productive inventors were more likely to work for large firms.

MARGARET LEVENSTEIN, University of Michigan, and NAOMI LAMOREAUX, University of California, Los Angeles 
A Retrospective Panel of Mid-Nineteenth Century Entrepreneurs: St. Louis Bank Promoters, 1857-1861

This paper profiles a group of entrepreneurs who organized six new banking corporations in St. Louis between 1857 and 1859. In doing so, they virtually founded the state's banking industry, despite having little prior banking experience themselves. Many of these men also promoted other important enterprises in the city. Preliminary analysis indicates that many group members fit the modern profile of the job-changing entrepreneur, with some differences that speak to the conditions of nineteenth-century business. This paper aims to contribute to our understanding of entrepreneurial behavior in rapidly growing and innovative economic regions, in this case one in which technological innovation played no part. The paper also sketches the new banks' role in transforming the wider regional economy.

MARK GEIGER, University of California, Los Angeles

SESSION 4C: AGRICULTURE, TECHNOLOGY, AND ADAPTATION

\section{Technology Creation and Diffusion and Its Economic Consequences in U.S. Agriculture in the Twentieth Century}

Many researchers and commentators underestimate the length and importance of the time lags between initial research investment and ultimate impacts on the development and adoption of technological innovations. In both econometric studies of productivity and ex post and ex ante benefit-cost evaluations of research investments, researchers typically impose untested assumptions about the R\&D lag, which can have profound implications for the results. In this paper, we present a range of evidence on agricultural R\&D lags including both aggregative analysis of U.S. agricultural productivity using time series data, and some specific details on the timelines for the research, development, and adoption processes for particular mechanical and biological innovations in U.S. agriculture. The aggregative analysis makes use of a comparatively rich state-level data set on U.S. agriculture that makes it possible to test hypotheses about the R\&D lag and to evaluate the implications for the specification of models of production and for findings regarding the rate of return to public research investments. The results support the use of a longer lag with a different shape than is typically imposed in studies of industrial R\&D. These findings are supported by the timelines for specific technological innovations, including new crop varieties, as well as tractors and other mechanical innovations.

\section{JULIAN Alston, University of California, Davis, and PHILIP PARDEY, University of Minnesota}

Response to Technological Change: The International Wine Industry, 1850-1939

The paper compares the response to technological change and demand for institutional innovation in five very different wine producing nations (France, Spain, Algeria, Australia, and the United States). The international transfer in knowledge associated with grape production, and in particular the rapid advances in eliminating the obstacles to successful winemaking in hot climates, radically changed the locus of production of the industry and in turn threatened the livelihood of many traditional 
growers. Yet while international changes in production technologies and the integration of national markets encouraged a concentration of economic activities everywhere, the political voice and bargaining power of growers, winemakers, and merchants differed greatly within individual countries. The paper discusses the political economy of institutional change and government intervention in each of the five countries in the areas of product adulteration, producer cooperatives, and appellation contrôlée.

JAMES SIMPSON, Universidad Carlos III de Madrid

\section{[Up and] Down on the Farm: Causes and Consequences of Tenure Mobility}

Our paper sheds light on the degree to which America represented the "land of opportunity" in the early part of the twentieth century. We have assembled data from all the original remaining manuscripts from the 1920 Census of Agriculture. We have observations on slightly more than 10,000 farmers from five counties in the five states of Illinois, Michigan, Montana, New Mexico, and Tennessee. This is the only agricultural census which allows us to assess mobility up the agricultural ladder from wage worker to tenant to owner. Given that our data set represents distinct agricultural regions of the country and agriculture was country's largest single job category at 25 percent of the labor force, we will be able to assess the degree of mobility and its determinants for a significant percentage of the labor force. Our preliminary research shows that tenancy was a means of economic and social advancement.

LEE Alston, University of Colorado

\section{PLENARY SESSION: ECONOMIC DEVELOPMENT: LEARNING FROM HISTORY}

There is increasing evidence that events during certain critical historical junctures have long-lasting influences on economic outcomes and particularly on economic growth. We do not currently know what the mechanisms responsible for these persistent effects are. This talk discusses a number of examples illustrating the role of major historical events on long-run development and argues that the effects work through institutional persistence and technology choices. It suggests potential reasons for why institutional equilibria triggered by historical events may have persisted for long periods. However, this emphasis on long-run implications of certain historical events means neither that all historical events have far-reaching consequences nor that history is destiny. The talk ends with an example illustrating how radical reforms can change the pattern of historical persistence.

Moderator, DARON ACEMOGLU, Massachusetts Institute of Technology Commentator: JOEL MOKYR, Northwestern University

\section{SESSION 5A: INDUSTRIALIZATION, COLONIZATION, AND TRADE IN ASIAN DEVELOPMENT}

\section{Taiwan's Industrialization: The Rise of a Demand-Responsive Economy}

This paper will describe and analyze the development of what we term a "demandresponsive economy." Drawing on hundreds of interviews done over a period of over fifteen years, this paper shows how supplier markets in Taiwan and later in China 
actually developed in response to the intermediaries, which are retailers and brand name merchandisers. These interviews allow us to specify how the Taiwan economy became organized "backwards" from the development of consumer markets in the United States to the development of suppliers markets for final and intermediate goods in East Asia.

GARY HAMILTON, University of Washington, and CHENG-SHU KaO, Tunghai University

\section{The Evolution of Export-Oriented Industries in Japan's Economic Development: From "Labour-Intensiveness" to "Skill-Intensiveness"}

This paper explores the role of small-scale industries in Japan's industrialization by focusing on the changing patterns of the export trade from the late nineteenth century to after World War II. Arguably, this is the best arena to examine this issue as entering export markets entails facing severe competition. It is well known that textile goods occupied the largest part of Japan's export continuously until the 1960s. Although the individual categories only accounted for small proportions, the sum of various consumer goods other than textiles contributed a considerable proportion of manufactured exports, with changing the patterns in the composition after World War I. We can assume that there was an evolutionary process in production and that the small-scale industries played a central role in it. In other words, the foundation of the competitive edge of Japan's export-oriented industries transformed from cheap female laborers at the large textile factories to the skilled or semiskilled male workers in the small workshops. We exemplify this process by focusing on the development of the urban toy industry in the interwar period and suggest that this form of industrial rivalry-competing for the affluent market in industrial finished goods - appears to have pioneered an important type of world trade, which expanded after World War II.

TANIMOTO MASAYUKI, University of Tokyo

\section{Land Property and Contract in Taiwan During the Qing and Japanese Colonial Period}

Taiwan, an island off the southeastern coast of China, has been largely reclaimed by Han Chinese from the mainland since the late seventeenth century. In the process, they instituted a multiple land rights and contract regime, which also characterized the land tenure of most areas in southern China during the Qing period. Afterwards, the regime was transformed into a single-owner land rights and contract regime by the Japanese colonial government. I first show how the old regime was formed via the long-term interactions between the Qing state and local societies and how it bolstered a rapid development and extension of agrarian market economy. However, I also analyze its limits in attracting more capital and modern technology. Secondly, I discuss how the colonial government reformed the old regime during 1898-1905 and compare the different functional logics of these two land regimes. I show that the new regime in colonial Taiwan supported a massive input of capital and technology, which stimulated a remarkable increase in land yields and productivity and made its market economy broader and more efficient. 


\title{
SESSION 5B: MALTHUS, MIGRATION, AND THE MODERN WORLD
}

\author{
Malthus to Modernity: Income, Fertility, and Economic Growth in England, 1500- \\ 1914
}

The Industrial Revolution seemingly involved two profound changes separated by 120 years: the classic Industrial Revolution of 1770 and the demographic transition of 1890 . The first was higher innovation rates, creating modern rates of output growth. The second a decline in fertility, first in the upper classes then in the masses, that channeled all economic growth into higher living standards. That 120-year chasm has been unbridgeable in unified accounts of the transition to modern growth. Measuring economic status and net fertility from wills, we show that the demographic transition actually coincided with the Industrial Revolution. Net fertility among the rich fell rapidly towards modern levels after 1770. But aggregate fertility rose in these years because net fertility among the poor at the same time rose to equal that of the rich. Only in the 1890 s did aggregate fertility rates begin to decline.

GREGORY ClARK, University of California, Davis, and NeIL CUMmins, London School of Economics

\section{Did Migrant Origins Matter? Migrants vs. Nonmigrants in Nineteenth-Century Germany}

This paper addresses a mostly ignored issue, how migrants compare to those who remained at home and focuses on mid-nineteenth-century emigrants who left the German principality of Hesse-Cassel during the 1850s, mostly for the United States. Annual village emigration rates ranged from 0 percent to 21 percent, indicating that the probability of emigration differed substantially across villages. Evidence from a GIS map of the principality shows geographic clusters of villages with high emigration rates as well as ones with low rates. Many villages with high emigration rates could also be located next to ones with low emigration rates only a few kilometers away. Such patterns suggest something distinct about different villages that played an important part in driving emigration rates. The econometric evidence indicates that more emigrants left villages that were relatively well-off in terms of land. Emigrants also left places that were more religiously diverse, had an abundance of artisans, substantial previous migration, unequal inheritance traditions, and a dearth of factories.

Simone WegGe, City University of New York

\section{A Fantastic Rain of Gold: European Migrants' Remittances and Balance of Payments Adjustment During the Gold Standard Period}

While the mass migration phenomenon that characterized the pre-1914 world has been widely studied, the related pattern of emigrants' remittances during the same period is still largely untouched. This paper aims at filling this gap by analyzing the contribution of remittances to financial stability during the classical gold standard. First, the paper presents a new data set of remittances received by five of the European countries with higher emigration rates between 1880 and 1914. Second, the paper shows how emigrants' remittances can help to finance external imbalances and buffer 
financial disturbances. Third, the paper tests this claim by showing that higher levels of remittances reduced the incidence of sudden stops and current account reversals. This effect is stronger for countries under the gold standard, since floating countries could rely on exchange rate fluctuations for their external adjustment.

RUI ESTEVES, University of Oxford, and DAVID KHOUdOUR-CASTÉRAS, CEPII Paris

\section{SESSION 6A: INNOVATION, COMPETITION, AND GROWTH}

\section{Does Economic History Need GPTs?}

In the last decade or so, one of the most successful memes in economic history has been the concept of a general purpose technology. The rapid multiplication of technologies accorded this designation has led some economic historians to question whether the concept has gotten out of hand. My intent in this essay is to ask whether the concept has indeed gotten out of hand, and, more fundamentally, whether, when the concept of a GPT and the ways it has been used are critically examined, we may conclude that the discipline of economic history could do as well without it. I note that the GPT criteria are not always consistently applied, the technologies under discussion are often not clearly identified, and that the criteria ultimately do a haphazard job of separating the consequential from the inconsequential.

ALeXANDER FIELD, Santa Clara University

\section{Schumpeterian Competition Within Computing Markets and Organizational Diseconomies of Scope}

We address a longstanding question about the causes behind creative destruction. Incumbent dominant firms, long successful in an existing technology, are often much less successful in a new technological era. We examine two of the most important historical episodes in computing markets, respectively, the introduction of the PC and the browser. We examine the internal organization of two contemporaneously leading computing firms, IBM and Microsoft. We show that organizational diseconomies of scope between new and old businesses explain the pattern of unsuccessful dominant firms in the two historical cases. Each firm, having been an extremely successful marketer of an old technology, came to have grave difficulties running an organization which could effectively market in both the old and the new technologies. Our analysis locates the problem that each had firmly in the marketing or commercialization of new technologies. It was in the area of the greatest strength of these firms, not in any area of weakness, that the organizational diseconomies of scope arose.

SHANE GREENSTEIN, Northwestern University, TIMOTHY BRESNAHAN, Stanford University, and REBECCA HENDERSON, Massachusetts Institute of Technology 


\section{More Machines or Better Machines}

Using an engineering production function and detailed information on major inventions in nineteenth-century cotton weaving, this paper assesses how much of the rapid growth in labor productivity arose from capital-labor substitution and how much from technical change. I find that labor-saving technical change accounts for almost all of the growth. However, much of the labor-saving bias arose not from inventions, but from acquisition of new knowledge and skills by weavers. Moreover, this was endogenous, influenced by wages and prices. This provides a technologybased explanation for the persistent association between economic growth and capital deepening.

JAMES BESSEN, Boston University

\section{SESSION 6B: IMPACT OF TRADE BARRIERS ON GROWTH}

\section{The Structure of Protection and Growth in the Late Nineteenth Century}

There is a vast literature on the relationship between trade policy and growth, including several papers on the late-nineteenth-century experience (e.g., O'Rourke 2000, Clemens and Williamson 2004). However, standard trade models suggest that the structure of protection, rather than the overall average tariff level, should matter for resource allocation and hence for growth. This paper assembles a database of agricultural, manufacturing, and revenue tariffs for ten countries between 1875 and 1913, and asks what the relationship was between each of these variables and (a) aggregate (b) sectoral growth.

\section{KeVIn O'Rourke, Trinity College, and Sibylle Lehmann, Trinity College}

\section{Engines of Development? Cross-Country Evidence on the Interconnection Between Private and State Railroad Construction and GDP, 1870-1912}

Economic development and railroad construction were interconnected during the period from 1870 to 1912 . This paper analyzes the short-term and longterm relationship between GDP, private railroad construction, and state railroad construction using panel cointegration and vector error correction models. The results show that the numbers of miles constructed by private companies and states are both cointegrated with GDP and GDP per capita. The results also show that GDP per capita had a positive short-run effect on private railroad miles, but not vice versa. By contrast, state railroad miles had a positive short-run effect on GDP, but not vice versa. These findings suggest that state railroad construction was an engine of development, while private railroad construction was more of a vehicle for profits.

DAN BOGART, University of California, Irvine 
Borders, Market Size, and Urban Growth: The Case of Saxon Towns and the Zollverein During the Nineteenth Century

Changes in trade institutions, like abolishment of tariff barriers, have a potentially strong impact on economic development. The Zollverein, the 1834 customs union between German states, erased borders in much of central Europe. This paper investigates the Zollverein's economic impact through a study of urban population and its growth in the German state of Saxony. A model of the effect of market access on urban growth is combined with an extensive data set on town populations in Saxony and its neighbors as well as an improved distance measure based on GIS techniques, which takes into account elevation patterns, roads, and rivers. Empirically, market access explains town size quite well and the results show that Zollverein membership led to significantly higher growth for towns close to the border with fellow Zollverein member, Thuringia. The results also illustrate that natural resources affect town size, but not the growth pattern after the Zollverein and market access had a stronger effect on larger towns. Migration was the predominant source of the differential growth pattern.

FLORIAN PlOECKL, Yale University 